\title{
MADU MENURUNKAN FREKUENSI BATUK PADA MALAM HARI DAN MENINGKATKAN KUALITAS TIDUR BALITA PNEUMONIA
}

\author{
Rokhaidah $^{1 *}$, Nani Nurhaeni ${ }^{2}$, Nur Agustini $^{2}$ \\ 1. Program Studi Magister, Fakultas Ilmu Keperawatan, Universitas Indonesia, Depok 16424, Indonesia \\ 2. Fakultas Ilmu Keperawatan, Universitas Indonesia, Depok 16424, Indonesia \\ *E-mail: rokhaidah@yahoo.com
}

\begin{abstract}
Abstrak
Gejala umum yang sering dirasakan balita pneumonia adalah batuk. Intervensi keperawatan mandiri yang dapat dilakukan untuk mengatasi masalah batuk pada malam hari dan kualitas tidur anak di antaranya adalah dengan memberikan terapi komplementer madu. Madu bermanfaat bagi kesehatan karena mengandung antibiotik alami, antiinflamasi, dan antioksidan. Penelitian ini bertujuan mengidentifikasi efektivitas pemberian madu terhadap batuk pada malam hari dan kualitas tidur balita yang mengidap pneumonia. Desain penelitian ini menggunakan rancangan eksperimen semu pretest posttest with non equivalent control group dengan tiga puluh enam responden yang diambil secara consecutive sampling. Hasil analisis data menggunakan independent t-test yang menunjukkan bahwa terdapat perbedaan penurunan skor batuk $(\mathrm{p}<0,001$; CI 95\% 1,82-3,37) dan peningkatan kualitas tidur yang bermakna ( $<<$ 0,001; CI 95\% 0,66-1,67) saat posttest pada kelompok yang mendapatkan madu dibandingkan dengan kelompok kontrol. Peneliti merekomendasikan pemberian madu bagi balita pneumonia sebagai terapi komplementer yang aman untuk mengatasi batuk.
\end{abstract}

Kata kunci: batuk, kualitas tidur, madu, pneumonia

\begin{abstract}
Honey for Decreasing Cough at Night and Increasing the Sleep Quality of Children with Pneumonia. A common symptom of pneumonia in toddler is coughing. Coughing is the body's natural mechanism in response to the inflammation that occurs in the lungs. Coughing that occurs at night can disrupt sleep quality of toddler with pneumonia. Independent nursing interventions that can be done to overcome this problem is to provide honey as a complementary therapy. Honey is very beneficial for health because it contains natural antibiotic, anti-inflammation, and antioxidant. This study aimed to identify the effectiveness of honey to decrease night time cough and to increase sleep quality of toddler with pneumonia. This study used a quasi-experimental pretest-posttest design with nonequivalent control group with 36 respondents taken by consecutive sampling. Results of data analysis using independent t-test showed differences decrease cough scores ( $p<0,001$; CI 95\% 1,82-3,37) and a significant increase in sleep quality ( $<<0,001 ; C I 95 \%$ 0,66-1,67). It is recommended to give honey to toddlers with pneumonia as a safe complementary therapy for treating coughs.
\end{abstract}

Keywords: cough, honey, pneumonia, quality of sleep

\section{Pendahuluan}

Pneumonia saat ini masih menjadi masalah kesehatan utama di beberapa negara di dunia, termasuk Indonesia. Hal ini dapat dilihat masih tingginya angka morbiditas dan mortalitas pneumonia, terutama pada balita. Upaya penanganan pneumonia difasilitasi oleh kesehatan tingkat dasar terintegrasi dalam Manajemen Terpadu Balita Sakit (MTBS).
Gejala klinis yang sering dirasakan balita atau anak dengan pneumonia adalah batuk. Batuk dapat terjadi sepanjang hari dan dapat mengganggu kenyamanan anak dalam beraktivitas. Batuk pada malam hari dapat menyebabkan kualitas tidur anak terganggu. Perawat sebagai pemberi asuhan utama dapat memberikan intervensi keperawatan yang aman dan efektif untuk membantu anak pneumonia yang mengalami batuk. Madu adalah salah satu terapi komple- 
menter yang dapat digunakan untuk membantu meredakan batuk pada malam hari sehingga dapat meningkatkan kualitas tidur anak.

Madu dapat diberikan kepada anak karena aman dan efektif menurunkan skor frekuensi batuk dan meningkatkan kualitas tidur anak seperti yang dijelaskan pleh Evans, Tuleu, dan Sutcliffe (2010), pengobatan dengan madu efektif untuk batukdan tidur anak. Penelitian oleh Shadkam, Mozafari-Khosravi, dan Mazayan (2010) menyebutkan bahwa madu dapat mengontrol batuk, lebih murah, mudah didapatkan dan aman untuk anak-anak. Penelitian Paul, Beiler, Mc Monagle, Shaffer, Duda, dan Berlin (2007) menemukan fakta bahwa madu adalah alternatif yang efektif dan aman untuk meredakan batuk pada malam hari dan mengatasi kesulitan tidur anak, madu bekerja sangat baik dalam mengurangi gangguan tidur akibat keparahan dan frekuensi batuk malam hari pada anak dengan infeksi saluran pernafasan atas dibandingkan dengan dextromethorphan maupun tanpa treatment.

Cohen, et al., (2012) menemukan ada perbedaan yang signifikan dari penurunan skor batuk dan skor kualitas tidur anak pada kelompok yang diberikan madu dibandingkan dengan kelompok plasebo. Tujuan penelitian ini untuk mengidentifikasi efektivitas pemberian madu terhadap batuk pada malam hari dan kualitas tidur balita dengan pneumonia.

\section{Metode}

Desain penelitian yang digunakan adalah kuasi eksperimen dengan pendekatan nonequivalent control group before after design. Responden dipilih dengan teknik consecutive sampling. Kriteria inklusi dalam penelitian ini adalah (1) anak yang sedang dirawat inap, (2) anak usia 1-5 tahun yang didiagnosis pneumonia/bronkopneumonia, (3) anak mendapat terapi medis berupa antibiotik, mukolitik, dan inhalasi, (4) anak dirawat pada hari pertama saat penetapan sebagai responden, (5) orang tua atau wali dapat diajak bekerja sama dan menyetujui anaknya menjadi responden penelitian. Kriteria ekslusi adalah anak pneumonia berat dan disertai kom- plikasi penyakit lain sehingga anak membutuhkan perawatan intensif. Instrumen yang digunakan adalah berupa kuesioner untuk data karekteristik responden dan lembar observasi orang tua/wali untuk skor frekuensi batuk dan skor kualitas tidur anak. Data awal diambil pada hari pertama anak dirawat dan data akhir atau post test diambil pada hari keempat.

Analisis data dilakukan dengan analisis univariat dan analisis bivariat. Analisis bivariat dilakukan dengan menggunakan uji parametrik (paired $t$ test dan independent $t$ test). Penelitian ini telah mendapatkan izin dari tim kaji etik Fakultas Ilmu Keperawatan Universitas Indonesia.

\section{Hasil}

Penelitian ini mengidentifikasi beberapa karakteristik responden, yaitu usia anak pneumonia berkisar 17,7 bulan sampai 19,4 bulan. Mayoritas berjenis kelamin laki-laki $(58,3 \%)$, status gizi sebagian besar $(63,8 \%)$ normal, mayoritas $(69,5 \%)$ tidak mendapatkan Air Susu Ibu (ASI) eksklusif dan mayoritas $(63,9 \%)$ anak pneumonia mendapatkan imunisasi Difteri, Pertusis, dan Tetanus (DPT) dan campak.

Dari Tabel 1 dapat dilihat bahwa ada perbedaan yang bermakna antara rerata selisih skor frekuensi batuk dan skor kualitas tidur kelompok

Tabel 1. Selisih Skor Frekuensi Batuk dan Skor Kualitas Tidur antara Kelompok Intervensi $(n=18)$ dan Kelompok Kontrol $(n=18)$

\begin{tabular}{lccc}
\hline \multicolumn{1}{c}{ Variabel } & $\begin{array}{c}\text { Rerata } \pm \\
\text { s.d. }\end{array}$ & $\begin{array}{c}\text { Interval } \\
\text { Kepercayaan } \\
(\boldsymbol{C I} \text { 95\%) }\end{array}$ & $\mathbf{p}$ \\
\hline $\begin{array}{l}\text { Selisih Skor } \\
\text { Frekuensi Batuk } \\
\text { a. Kelompok } \\
\text { Intervensi }\end{array}$ & $6,22-1,76$ & $\begin{array}{c}2,78 \\
(1,82-3,73)\end{array}$ & $<0,001$ \\
$\begin{array}{l}\text { b. Kelompok } \\
\text { Kontrol }\end{array}$ & $5,05-1,62$ & & \\
\hline $\begin{array}{l}\text { Selisih Skor } \\
\text { Kualitas Tidur } \\
\text { a. Kelompok } \\
\text { Intervensi }\end{array}$ & $2,27 \pm 0,82$ & 1,17 & $<0,001$ \\
$\begin{array}{l}\text { b. Kelompok } \\
\text { Kontrol }\end{array}$ & $1,50 \pm 0,51$ & & \\
\hline
\end{tabular}


intervensi dengan kelompok kontrol. Selisih skor frekuensi batuk dan skor kualitas tidur kelompok intervensi lebih tinggi secara bermakna dibandingkan dengan kelompok kontrol $(\mathrm{p}<0.001)$.

\section{Pembahasan}

Hasil penelitian ini sesuai dengan penelitian Cohen, et al., (2012) yang menemukan skor frekuensi batuk dan skor kualitas tidur anak yang mengalami infeksi saluran pernafasan akut pada kelompok yang diberikan madu menunjukkan penurunan yang bermakna pada saat post test dibandingkan dengan kelompok kontrol. Warren, Pont, Barkin, Callahan, Caples, Carol, dan Plemmons (2007) juga menemukan bahwa terdapat perbedaan penurunan skor batuk yang signifikan antara kelompok yang diberikan madu dengan kelompok kontrol, penurunan skor batuk pada kelompok intervensi lebih besar dibandingkan dengan kelompok kontrol. Penelitian lain dari Paul, et al., (2007) tentang efek madu, dextromethorphan, dan tanpa intervensi terhadap batuk malam hari dan kualitas tidur anak dan orang tua, didapatkan hasil terdapat perbedaan penurunan skor frekuensi batuk yang signifikan pada kelompok yang diberikan madu dibandingkan dengan kelompok lainnya. Rerata penurunan skor frekuensi batuk dan skor kualitas tidur pada kelompok yang diberikan madu lebih tinggi dibandingkan dengan kelompok dextromethorphan dan kelompok tanpa intervensi. Hasil penelitian ini dan penelitian serupa tentang efek madu terhadap batuk pada malam hari dan kualitas tidur anak telah membuktikan bahwa madu efektif untuk mengurangi frekuensi batuk dan memperbaiki kualitas tidur. Manfaat ini terkait dengan komposisi madu yang mengandung zat-zat unik yang sangat bermanfaat untuk kesehatan. Alquran surah An-Nahl (lebah) ayat 69 menjelaskan tentang manfaat madu, yang artinya "Kemudian makanlah dari tiap-tiap (macam) buah-buahan dan tempuhlah jalan Tuhanmu yang telah dimudahkan (bagimu). Dari perut lebah itu keluar minuman (madu) yang bermacammacam warnanya, di dalamnya terdapat obat yang menyembuhkan bagi manusia. Sesungguhnya pada yang demikian itu benar-benar terdapat tanda (kebesaran Tuhan) bagi orang-orang yang berpikir."
Penurunan skor frekuensi batuk pada anak setelah diberikan madu terjadi karena madu mempunyai kandungan antibiotik alami, antioksidan, dan kombinasi zat-zat lain. Selain itu, madu merupakan komponen penting yang dapat membantu meringankan batuk anak-anak. Madu berfungsi melapisi tenggorokan dan memicu mekanisme menelan, rasa manis pada madu akan mengubah sensitivitas serabut sensori. Ada interaksi antara saraf sensori lokal dengan sistem saraf pusat yang terlibat dalam regulasi mekanisme batuk sehingga mampu meredakan batuk (McCoy dan Chang, 2013).

Di Indonesia, penyebab tersering pneumonia pada anak adalah dari jenis bakteri. Menurut Bogdanov (2011), madu mempunyai efek antimikroba langsung dan tidak langsung. Efek madu sebagai antimikroba langsung adalah dengan menghambat pertumbuhan mikroorganisme, madu memiliki efek bakteriostatik dan bakterisida. Oksidase glukosa madu menghasilkan agen antibakteri hidrogen peroksida, sedangkan agen antibakteri nonhidrogen peroksida antara lain kandungan gula yang tinggi pada madu menyebabkan efek osmotik gula, $\mathrm{pH}$ bersifat asam, kandungan fenolat dan flavonoid, serta kandungan protein dan karbohidrat madu yang semuanya bertanggung jawab atas aktivitas antibakteri sehingga madu dapat membantu melawan agen penyebab pneumonia anak. Ajibola (2012) menjelaskan bahwa madu dapat merangsang dan meningkatkan produksi antibodi selama proses pembentukan imunitas primer dan sekunder.

Peningkatan kualitas tidur yang signifikan pada saat posttest kelompok yang diberikan madu sebelum tidur disebabkan oleh madu dapat merangsang pengeluaran hormon melatonin yang berfungsi memicu pelepasan hormon pertumbuhan yang mengatur pemulihan fungsi fisiologis tubuh, memelihara dan membangun kembali tulang, serta otot dan jaringan tubuh lainnya. Semua itu terjadi pada waktu malam. Melatonin berdampak pada konsolidasi memori dengan pembentukan molekul adhesi sel saraf selama tidur rapid eye movement (REM). Bersamaan dengan itu, fruktosa dalam madu diserap oleh hati untuk diubah menjadi glukosa kemudian menjadi 
glikogen sehingga mampu memasok kebutuhan glukosa otak dengan cepat pada waktu malam. Selain itu, fruktosa mengatur penyerapan glukosa ke dalam hati dengan merangsang pelepasan glukokinase. Fruktosa memastikan pasokan glikogen hati selama semalam dan mencegah lonjakan glukosa, insulin, dan pelepasan hormon stres (McInnis, 2008).

\section{Kesimpulan}

Hasil penelitian ini dapat disimpulkan bahwa madu terbukti efektif menurunkan skor frekuensi batuk malam hari dan meningkatkan kualitas tidur anak balita dengan penumonia. Hasil penelitian ini juga dapat menjadi bahan masukan atau pertimbangan bagi perawat anak untuk dijadikan sebagai bagian dari intervensi keperawatan dalam merawat anak yang mengalami pneumonia. Penelitian berikutnya perlu dikembangkan kembali, yaitu penelitian manfaat madu terhadap batuk pada malam hari serta kualitas tidur anak dan orang tua yang mengidap pneumonia (YR, INR, AM).

\section{Referensi}

Alquran, Surah An-Nahl, ayat 69.

Ajibola, A., Chamunorwa, J. P. \& Erlwanger, K. H. (2012). Nutraceutical values of natural honey and its contribution to human health and wealth. Nutrition metabolism, 9, 61. doi:10.1186/1743-7075-9-61.
Bogdanov, S. (2011). Honey as nutrient and functional food: A review. Bee Product Science, 3(2), 1-33. Diperoleh dari www.beehexagon.net.

Cohen, H.A., Rozen, J., Kristal, H., Laks, Y., Berkovitch, M., Uziel, Y., et al. (2012). Effect of honey on nocturnal cough and sleep quality: A doubleblind, randomized placebocontrolled study. Pediatrics, 130 (3), 1-9.

Evans. H., Tuleu. C., \& Sutcliffe. A. (2010). Is honey a well-evidenced alternative ti overthe-counter cough medicines? Journal of $R$ Social Medicine, 103, 164-165.

Paul, I.M., Beiler, J., Mc Monagle, A., Shaffer, M.L., Duda, L., \& Berlin C.M. (2007). Effect of honey, dextromethorphan, and no treatment on nocturnal cough and sleep quality for coughing children and their parent. Archive of Pediatrics Adolescent Medicine, 161 (12), 1140-1160.

Shadkam, M.N., Mozaffari-Khosravi, H., \& Mozayan, M.R. (2009). A comparison ofthe effect of honey, Dextromethorphan,and Diphenhydramine on nightly coughand sleep quality in children and their parents. The Journal of Alternative and Complementary Medicine, 16 (7), 787-793.

Warren, M.D., Pont, S.J., Barkin, S.L., Callahan, S.T., et al., (2007). The effect of honey on nocturnal cough and sleep quality for children and their parents. Archives of pediatrics \& adolescent medicine, 161 (12), 1149-1153. 